\section{THE COMMISSION ON HIGHER EDUCATION, 1967, AND THIRD-LEVEL POLICY IN CONTEMPORARY IRELAND}

John Coolahan

While higher education did not feature prominently in the public consciousness during the first four decades of political independence, the following twenty years witnessed a remarkable degree of analysis and appraisal and a level of action on a range of fronts which transformed the provision and profile of higher education in Irish society. By 1960 the Government accepted that the whole question of third-level education needed to be examined and that third-level education would be a crucial element in the planned socio-economic development of the state. With this end in view, the Minister for Education, Dr. Hillery, appointed a twenty-eight person commission on Higher Education. It held its inaugural meeting on the 8 th November, 1960 . It's terms of reference were very wide and, in effect, included the surveying of every feature of higher education:

Having regard to the educational needs and to the financial and other resources of the country to inquire into and to make recommendations in relation to university, professional technological and higher education generally.... 1

This was the first comprehensive survey of higher education in Ireland and the first commission since independence to examine the academic and administrative issues involved in higher education. Perhaps it was the freedom given, and the vast range of issues which were examined that led to serious problems about the duration of the Commission's work, as well as some of the solutions it felt necessary to propose. The Commission took seven years to conclude and present it's report. This was a very long time at a period when many educational issues were pressing for resolution.

It is worth noting that while the Commission was engaged on it's deliberations a number of inquiries were simultaneously set up on Irish education and a number of decisions were being arrived at by Government. Just as the Commission was the first major survey of Higher education, the Investment in Education inquiry, jointly established by the Irish Government and the O.E.C.D. in 1962, was the first comprehensive survey of the first and second-level systems. In 1963 a joint study was also undertaken with the O.E.C.D. on scientific research and technology in relation to Irish economic development. Furthermore, in 1963, the Minister for Education announced his intention of establishing regional technical colleges and in 1966 the Minister set up a steering committee on technical education to advise him on regional technical colleges. In December 1966, the Minister for Education brought his major proposal for merging Trinity College Dublin with U.C.D. to the cabinet, which deferred a decision on it pending the conclusion of the Commission's report. By this stage the delay in concluding the Commission's report was giving rise to political controversy and acrimony. Only the intervention of the Taoiseach, Seán Lemass, in December 1966 prevented the resignation of the Chairman, Cearbhaill Ó Dálaigh. 2 Lemass had himself written to the Chairman the previous July, 1966, urging an early completion to the work. . O Dálaigh's reply highlighted the key issue of attempting "within a single report to deal adequately with every main question." 3

A study of the minutes of the Commission's meetings indicates the divergence of views among Commission members on many of the issues raised. Disagreements between Commission members was also evidenced by the fact that twelve members submitted notes of reservation on many significant recommendations. The Commission approached its work in the traditional "grand" style of commissions of an earlier era. The work occupied members' time on a total of 309 days. A total of 154 witnesses gave oral evidence, while written submissions amounted to 1.1 million words. Members of the commission made 77 visits to educational institutions, many of the visits to international centres. The report, as published in 1967 , comprised Part 1 Presentation and Summary (approximately 25,000 words) and the Report proper in two volumes comprising 400,000 words. It was planned to publish a volume of appendices and summaries of the written and oral evidence and it was recommended that copies of the complete text of the written submissions and oral evidence be placed in academic and public libraries. These plans were never put into effect. This was a significant loss to a public which had had little exposure to serious debate and views on higher education. The thirty two chapters of the published report were by far the most thorough effort ever undertaken to examine and to make proposals on every key feature of higher education in Ireland.

The Report was well organised with chapters being grouped into seven divisions. In the first instance, the Commission set out 
the structure of the existing provision for higher education and made an assessment of this. The assessment painted a rather dismal picture of the existing situation but one which influenced the Commission greatly in its recommendations for the future. It stated:

The existing system of higher education was developed piecemeal; it is not a unified system but a complex of separate units, involving some unnecessary duplication and leaving areas of higher education unprovided for. Sectional interests play too large a part, and antagonisms between individual institutions have been apparent. There is, as a rule, no planning machinery for the system and too little planning on the part of it's component institutions .... The standard of entry to the N.U.I. colleges that applied up to $1966 / 67$ was too low for university entrance....

Increasing numbers of students, low entry standards, and inadequate staffing and accommodation have produced a highly unsatisfactory situation, in which academic standards are endangered despite the efforts of academic staff to keep them as high as possible.

Their (the institutions') achievement is less impressive at the level of postgraduate studies and research, where the insufficiency of staff, equipment and accommodation has been especially frustrating.

The question of academic appointments in the National University of Ireland is unsatisfactory, especially because it does not ensure that candidates are assessed by those best qualified to make expert judgements on their merits.

The constitution of the N.U.I. and its constituent colleges, which has remained unchanged since 1908 has become unsuited in several important respects to the needs of a modern university. The constitution of T.C.D. has been more adaptable but it also needs adjustment. The constitutions of the teacher training colleges, and the higher technical and vocational colleges, which lack any academic self-government also call for change. 4

These summary, but unambiguous statements pointed up some of the serious problems which existed and raised fundamental questions which the Commission set down and endeavoured to answer. From the point of view of the Commission, the inadequacies which were revealed were "so grave as to call for a concentrated effort to remove them," and they were regarded as seriously militating "against the attainment of adequate academic standards." In turn, the Commission considered "Inadequate standards could endanger the whole fabric of our education." 5

In trying to establish a basic guideline from which to assess future development the Commission set down "a view of the University." It stated:

The university is not a professional academy, or congregation of professional academics, existing merely to provide a training for the several professions.... The university is a place for the study and communication of basic knowledge.... The university adds to existing knowledge and advances it beyond the present frontiers. 6

The Commission went on to draw a distinction between basic and applied learning, and between training in the scientific or philosophical principles, on the one hand, and training in techniques and practice, on the other. It stated that:

study of first principles is the distinctive function of the university's major obligation in professional training. 7

In a later section dealing with the university and technology the Commission decided that the responsibility for technological education should not lie with the university. ${ }^{8}$ Throughout the report there is a consistent view that the university was concerned with first principles and basic research as distinct from professional training and applied research. This view, coupled with the concern about safeguarding standards, which it regarded as seriously threatened by existing circumstances, underlay many of the individual specific recommendations of the Commission. They formed the pivotal axis of the Report's analysis and pointed the direction for the future, as the Commission viewed it.

The Commission was reporting at a time when there was a strong consciousness, which was going to become more pronounced, of a need and demand for greatly expanded provision of third-level places. It was concerned that the existing inadequate university resources would be in danger of being swamped by student numbers and the work of the universities be diluted in providing for part-time courses and a constantly expanding range of courses of applied 
training. The solution the Commissioners devised was to protect the existing universities for what they saw as their rightful rôle and for appropriate standards by proposing a new type of third-level institution - the New College - and diverting some of the applied professional work on to institutions with this specific purpose.

The New College was devised essentially to help meet the growing demand for third-level places, to enrich the intellectual and cultural life of the provinces and to provide forms of third-level education, lower in standard and different in emphasis from what the university should be concerned with. It was intended that the New College would operate in three major fields - the humanistic, and scientific and the commercial. It would work to the standard of the pass degree then in operation and also offer a range of shorter courses and could incorporate a vocational emphasis. Interestingly, the Commission ruled out the desirablility of a technological university, nor did it recommend a reconstitution of the colleges of technology under the Dublin V.E.C. to the status of advanced colleges of technology, on the lines of the contemporary British polytechnics. It did, however, recommend the setting up of a Technological Authority which would have responsibilities for ensuring that advanced technological education, training and research were provided in relation to the needs of Irish industry. Surprisingly, little reference was made to the proposed regional technical colleges, perhaps because these were initially seen as doing a good deal of second-level work.

Linked to its views on the distinctions between basic and applied learning, the Commission recommended the establishment of a separate National College of Agricultural and Veterinary Sciences "as a fully integrated teaching and research organision of university standing." On the other hand, the education and training of secondary teachers was to remain within the university, with the subject Education being raised in status as a central subject of university study. Primary school teachers would study for a degree of the New Colleges. The Committee saw no prime facie case for closing any of the five existing medical schools and while it endorsed certain reorganisation of the schools of dentistry it suggested few significant changes in dental education. The Commission recommended that "the fundamental study of law and research in law should be firmly established within the university system," while "training in the professional subjects and in legal practice should continue to be provided by the law societies themselves." 9 The same principle applied to studies in business and administration; the university being concemed with fundamental studies in these fields, and the vocational education system and the New Colleges providing more vocational and professional requirements.
The Commission urged that "positive relationships" should be established between the university and the independent research institutes while new research should be concentrated within the university or the institutes.

Another key area which was examined by the Commission was the future structure of the existing university institutions. The N.U.I. federal solution of 1908 was evaluated within the context of the $1960 \mathrm{~s}$ and in the light of the evidence presented to the Commission. U.C.D. argued strongly for the dissolution of the N.U.I., while U.C.C. and, particularly, U.C.G. favoured its retention. The Commission came down unequivocably in favour of the dissolution of the N.U.I., with the constituent colleges being established as separate and independent universities. Cork and Galway were to be given explicit guarantees as to their development, endowment and staffing. The options of independent status, or new links with the reconstituted U.C.D., were held out for Maynooth College, without a specific recommendation.

One of the issues which involved prolonged and very divided opinion within the Commission related to the rôle of Trinity College within Irish society. This problem was rooted in the historical attitude of Trinity to the university question in the early years of the century and to traditional attitudes of and towards Trinity as being less than fully integrated with the life and culture of independent Ireland. Few shared the President of U.C.D.'s view when he stated "Close down Trinity College. I look on T.C.D. as a foreign body and I think the whole Trinity tradition is something that we cannot assimilate into the national life."10 Rather, the eloquent and persuasive case put by Trinity representatives, Provost McConnell, Professor Moody and Basil Chubb won the assent of the Commission. It regarded Trinity as an asset "to the intellectual and cultural life of the country and affirmed that it had a proper place in the structure of Irish higher education."11

One of the main obstacles to the more full integration of Trinity into the mainstream of Irish higher education was the ban imposed by the Irish Catholic Hierarchy on attendance of Catholics at Trinity, without specific episcopal permission. Two members of the Commission, Bishops Philbin and Conway maintained an uncompromising stand on the ban issue and, while regarding the ban as "a national tragedy," the T.C.D. representatives accepted the Catholic Church's regulations with regret. The Commission itself took no position on the ban but allowed the inclusion of a long statement by Bishop Philbin setting out the Church's position in its final report. The Commission did not consider it opportune to contemplate associating T.C.D. and U.C.D. as a single Dublin-based 
university. Accordingly, it's recommendations involved two separate Dublin universities but the Commission hoped that, despite "antagonisms of the past" the two universities would develop cordial and satisfactory relationships. It is interesting to note that despite the fundamentalist position expressed to the Commission on the hierarchy's ban on Catholic attendance at T.C.D., the ban was removed in 1970 by the bishops. Furthermore, even before the Report was published, the Catholic hierarchy, in June 1966, took the decision to open Maynooth as a centre of higher studies to involve nuns, brothers and laity.

The Commission was strongly of the view that there was a need for much greater coördination and coöperation between the universities. It recommended the establishment of a statutory Council of Irish Universities with the right to decide on a number of issues such as entrance and degree standards, extern examining, exchange of information and policy, development and research, post-graduate schemes. It also hoped that formal relationships might also be developed between the universities and other third-level institutions. As an intermediary planning and budgetary agency between the State and individual institutions the Commission recommended the establishment of a statutory Commission for Higher Education, which "would be the keystone of the future structure of higher education." 12

Among a range of other important issues considered by, and reported on by the Commission were the following. It set out new governing and administrative structures for the universities and other third-level institutions. An area which had caused a good deal of controversy and dissatisfaction, particularly within the N.U.I. system was the process of academic appointments. The Commission set out new procedures of appointment for all the third-level colleges and conditions of service for appointees including the presidents of institutions, who should hold office for five years, renewable for a further term. Student entry standards were to be raised. The Commission urged an improvement of general staff-student ratios to $1: 12$ with adequate provision for small group teaching. It urged that at least 50 per cent of staff time should be allocated for research and private study. Regarding research as "the hallmark of a university" the Commission stressed that it's "comparatively undeveloped state" in Ireland required attention, and post-graduate study needed promotion. To facilitate student access to higher education "a comprehensive scheme of educational grants" should be introduced. Organisations of students were recognised as having a positive rôle to play and a national association of students should be grant-assisted. It was further urged that suitable student facilities meeting rooms, restaurants and common rooms - should have a definite place in the planning of institutions of higher education. Overall, the Commission was conscious that it's recommendations called for a greatly increased investment in higher education but considered that the investment would provide outlets for individual fulfilment and was a precondition of social and economic progress in Ireland.

The Commission had laboured hard and long on it's very wide-ranging terms of reference. The neglect of higher education for so long meant that the Commission had to deal with a great many issues. However, it considered that it's report provided an integrated framework for many of the issues which had to be addressed. It had endeavoured to isolate some fundamental problems and to proceed to build a framework based on that analysis.

The Commission's Report had been impatiently awaited. The Report was signed on 24th February 1967. Reaction to the Report's analysis and recommendations was mixed and the time-span involved since it began it's deliberations meant that new thinking and initiatives were under way which did not facilitate it's overall framework being appraised in a calm, considered way. Public attention quickly focussed on a number of specific issues and the controversy surrounding those tended to distract attention from the overall plan.

Many of the specific disagreements were rooted in the basic core of the Commission's analysis. The distinction between basic and applied leaming, separating the latter from the proper rôle of a university was seen by many as a basic error indicating a wrong direction for the future of university studies. A striking instance of this was alluded to in the proposal to set up an independent College of Agriculture and Veterinary Sciences. The concern of the Commisssion at the serious crisis it uncovered regarding university education - under-financed, under-staffed, poorly equipped, badly housed - made the Commission members fearful that a deluge of aspiring students would greatly imperil the existing university structure. It took the view of recommending the New Colleges as a mechanism for containing some of the new demand without injuriously affecting standards in the existing universities. Many saw this as an undesirable and unacceptable option. This was particularly so in the opposition to the proposal to provide the long sought degree for national teachers through the mechanism of a New College.

In any case, the New College proposal was to some extent already upstaged by the Govemment decision to establish regional 
technical colleges. In September 1966 a steering committee on technical education had been appointed by the government to advise it generally on technical education and, in particular, on building arrangements for the new regional technical colleges which the government had already decided to establish. It presented an interim report in January 1967 and a final report in April 1967, thus coinciding generally with the presentation of the Commission's Report. The steering committee was expected to take the Commission's recommendations into account. The rôle Commission's recommendations into account. "to educate for trade and industry over a broad spectrum of occupations ranging from craft to professional level, notably in engineering and science but also in commercial linguistic and other specialities" and being "capable of continuing adaptation to social, economic and technological changes." 13

The Steering Committee expressed disagreement with the Commission's views on entry standards and on the levels of academic qualifications proposed for the New Colleges. In general, it endorsed the Government's plans for regional technical colleges and largely ignored consideration of how they might mesh with the proposed New Colleges, except in the case of Limerick where it was felt the two institutions might retain their separate indentities and be felt the two institutions might retain their separate recommended the establishment of a National Council for Educational Awards with responsibility for syllabus and course validation in technical education, on the lines of the N.C.C.A. in Britain. Even though similarities existed between the Commission's proposal on a Technological Authority and the Steering Committee's proposal on an N.C.C.A., the thrust of the Steering Committee's report pointed more firmly towards a binary third-level framework on the lines of Britain, rather than the Commission's Report which saw the universities and the New Colleges conducted within a university type model, with less emphasis on technical and technological education.

A contemporary development which gave rise to greater public attention was the divergence between Government thinking on the future structure of university education and that of the Commission. While the Commission recommended the dissolution of the N.U.I. in favour of independent status for it's constituent colleges, and non-intereference with the independent status of Trinity College, the Minister for Education, Mr. O'Malley, rejected this advice. On 18th April 1967 he made the dramatic announcement that it was the Government's intention to establish a single multi-denominational university in Dublin, to contain two colleges, based on the existing institutions, University College and Trinity
College. The Minister was not unaware of the significance of such a proposal remarking, "It marks the end of an era in the long story of university education in Ireland, and also, it seems to me, in the history of the country itself." 14 The Minister argued that his proposal made economic, educational and social sense.

The Minister's dramatic announcement caught the imagination of the general public. This perspective was not, however, shared by many interested parties and very divergent views were expressed in what became a celebrated controversy, known popularly as "the merger proposals." The Governing Body of U.C.D. accepted the reasoning of the Minister that there should not be two universities in Dublin but proposed "a complete unification of the two universities" rather than the continued existence of two complementary colleges. Both U.C.D. and T.C.D. would now be absorbed in the New University of Dublin, an integrated institution although located on different sites. Trinity College was opposed to the idea of a unitary university, sensing a danger of the absorption of T.C.D. by the larger U.C.D. in such an arrangement.

The rejection by O'Malley of a key recommendation of the Commission regarding the university question in Dublin in his flamboyant "Merger" counter proposal, and the rejection of the "New Colleges" tended to foster a general attitude that the Report was irrelevant and it has suffered under the cloud of irrelevance since that time. This is an unfair and inaccurate assessment of both it's worth and it's influence. Many of it's specific proposals were adopted or implemented in an amended form. Apart from this, it's demarcation of the university's rôle in it's basic research and pure scholarship dimension from the applied research technological and vocational emphasis formed a basis on which a binary approach could be and was constructed. It's New College proposal was devised largely to protect inadequately resourced universities from having to cope with a great new influx of certificate, diploma and pass degree students over a range of studies, including those of a vocational emphasis. One of it's bedrock points was that academic standards should be maintained and strengthened. There was apprehension that the universities would be tempted to do too much with too little. The emergence of the regional technical colleges, the N.I.H.E.s and D.I.T. could be seen as having fulfilled a somewhat similar function, at least for a period of time. Under a range of other headings it's proposals could be regarded as very timely and necessary to focus attention on and to promote much needed reforms in Irish higher education.

With regard to legislation to reshape Irish third-level education one of the most remarkable features in later years was the 

1967. The dynamic of government took a different emphasis from that favoured by the Commission. The Commission, by confining the university's rôle to it's basic research and pure scholarship dimension and by distancing it from the applied research, technolons, provided a conceptual basis which prompted civil servants and government to drive ahead with which prompted civil servants and goverse latter dimensions the setting up of new institutions to promote these latter dimensions
of policy. The non-university sector became much closer to the policy makers' hearts.

The past twenty years have witnessed remarkable changes in Irish higher education. The expansion in student numbers has been most impressive. There have been many structural changes in the system with successful new bodies such as the Higher Education Authority and the National Council for Educational Awards firmly Authority and the National Council for Educational Awards firmly in place. A host of new third-level institutions have appeared on the Irish landscape. In line with developments internationally, higher education has become increasingly an instrument of government social and economic policy. The building up of the binary system has provided the government with a host of institutions amenable to it's concerns for technological, scientific and applied education. The it's concerns for techno non-university sector now holds more than 50 per cent of the greatly expanded student population. The university sector itself has also greatly altered and it's emphases have increasingly coincided with the greatly altered and it's emphases have increasingly coincided with the strongly stated government's priorities in higher education. The vocational emphasis of higher education today reflects a climate strikingly different from that which produced the attitudes of the strikingly different from that which produced the attitudes of Commission on Higher Education in the mid sixties. Legislation in January 1989 establishing two new universities, based on the two National Institutes of Higher Education, is a remarkable testimony as to how changed the climate has become and to the contrasting concept of university education now held to that put forward by the Commission on Higher Education in 1967.

mission on Higher Education, Report, Vol.1, Part 1, (Dublin : Stationery Office, 1967, pr.9389), p.xxviii.

2. Minutes of the Commission, Vol.X, pp.2098.

3. Minutes of the Commission, Vol:X, pp.2057.

4. Commission on Higher Education, I,

Presentation and Summary of Report

(Dublin : Stationery Office, 1967, pr.9326), pp.22, 23.

5. Report, Vol.1, part 1, p.121.

6. Ibid., p.122.

7. Ibid., p.143.

8. Ibid., p.184

9. Presentation and Summary of the Report, p.40.

10. Minutes of the Commission, Vol.XI, p.119.

11. Presentation and Summary of the Report, p.49.

12. Ibid., p.55.

13. Steering Committee on Technical Education, Report to the Minister on Regional Technical Colleges, (Dublin : Stationery Office, 1969, prl.371), p.11.

14. Statement of the Minister for Education, Mr. O'Malley, "University Education in Dublin," Studies, Summer 1967, Vol.LVI, No.222, pp.113-121. 